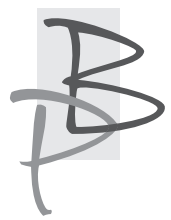

Ewa Witkowska*

Biblioteka Uniwersytecka im. Jerzego Giedroycia

https://orcid.org/0000-0002-5236-1970

Wiesław Wróbel*

Biblioteka Uniwersytecka im. Jerzego Giedroycia

https://orcid.org/0000-0002-4673-5761

\title{
Nieznane rękopisy Feliksa Schobera w zbiorach Biblioteki Uniwersyteckiej im. Jerzego Giedroycia w Białymstoku
}

Streszczenie: Na początku lat 80. XX wieku do Biblioteki Głównej ówczesnej Filii Uniwersytetu Warszawskiego w Białymstoku trafił pokaźny księgozbiór profesora Bronisława Wieczorkiewicza, przekazany po śmierci tego wybitnego językoznawcy i uczonego. Wśród ofiarowanych woluminów, głównie XIX- i XX-wiecznych publikacji, znalazło się kilka rękopisów. Na szczególną uwagę zasługują trzy rękopisy zawierające niepublikowane wcześniej sztuki oraz odręczne notatki i wiersze sporządzone w latach 1863-1866 przez Feliksa Schobera (1846-1879) - komediopisarza, tłumacza i aktora, jednego z przedstawicieli warszawskiego dramatu popularnego. Głównym celem artykułu jest przybliżenie życiorysu Feliksa

Ewa Witkowska - mgr, absolwentka filologii polskiej oraz informacji naukowej i bibliotekoznawstwa na Uniwersytecie w Białymstoku, obecnie starszy bibliotekarz w Bibliotece Uniwersyteckiej im. Jerzego Giedroycia w Białymstoku. Ma na swoim koncie wystąpienia i artykuły dotyczące różnych aspektów działalności bibliotek; e.witkowska@uwb.edu.pl

Wiesław Wróbel - mgr, absolwent historii na Uniwersytecie w Białymstoku, obecnie kierownik Pracowni Zbiorów Specjalnych i Digitalizacji w Bibliotece Uniwersyteckiej im. Jerzego Giedroycia, w ramach której prowadzi badania historyczno-proweniencyjne dokumentów zgromadzonych przez Bibliotekę. Jego badania historyczne skupiają się także na historii Białegostoku i Białostocczyzny w XIX i w 1 poł. XX w.; w.wrobel@uwb.edu.pl 
Schobera i jego dorobku literackiego, a także omówienie nieznanych rękopisów jego autorstwa znajdujących się w zbiorach Biblioteki Uniwersyteckiej im. Jerzego Giedroycia w Białymstoku.

Słowa-klucze: zbiory specjalne, teatr warszawski, historia teatru, dramat popularny, polski dramat dziewiętnastowieczny.

\section{The unknown manuscrips of Feliks Schober in the collection of the Jerzy Giedroyc University Library in Bialystok}

Summary: At the beginning of the 1980s, the Main Library of the then Warsaw University Branch in Bialystok received a large book collection belonging to the deceased professor Bronisław Wieczorkiewicz, a prominent linguist and scholar. It featured mostly volumes published in 19th and 20th century, but there were several manuscripts among them as well. There are three items that are of particularly noteworthy: these include unpublished plays, notes, and poems written between 1863 and 1866 by Feliks Schober (1846-1879), a comedy writer, translator and actor, one of the representatives of Warsaw popular drama. The main aim of this article is to present Feliks Schober's biography and works, as well as to discuss the unknown manuscripts of his authorship belonging to the collection of the Jerzy Giedroyc University Library in Bialystok.

Key words: special collection, Warsaw theatre, history of theatre, popular drama, Polish nineteenth-century drama.

\section{Wstęp}

Na początku lat 80. XX wieku do Biblioteki Głównej ówczesnej Filii Uniwersytetu Warszawskiego w Białymstoku trafił pokaźny księgozbiór Bronisława Wieczorkiewicza (1904-1974), profesora zwyczajnego Uniwersytetu Warszawskiego. Profesor Wieczorkiewicz był wybitnym językoznawcą oraz prekursorem polskiej socjolingwistyki. Wśród jego licznych zainteresowań badawczych (leksykografia, metodyka nauczania języka polskiego i języków obcych czy język mówiony jako tworzywo artystyczne) znalazły się także 
gwary miejskie i środowiskowe - pozostawił między innymi wnikliwe monografie dotyczące gwary warszawskiej ${ }^{1}$. Z tego względu wśród przekazanych do Białegostoku woluminów, głównie XIX- i XX-wiecznych publikacji, znalazło się kilkanaście różnych rękopisów. Wśród nich na szczególną uwagę zasługują trzy bruliony zawierające niepublikowane wcześniej sztuki² oraz notatki i wiersze Feliksa Schobera ${ }^{3}$, warszawskiego aktora, tłumacza i komediopisarza, sporządzone w latach 1863-1866, a więc w okresie, gdy rozpoczynał on pracę w Warszawskich Teatrach Rządowych.

Głównym celem niniejszego artykułu jest przedstawienie życiorysu Feliksa Schobera i jego dorobku literackiego wraz z omówieniem trzech nieznanych rękopisów jego autorstwa znajdujących się w zbiorach Biblioteki Uniwersyteckiej im. Jerzego Giedroycia w Białymstoku.

\section{Feliks Schober}

Feliks Józef Schober ${ }^{4}$ (inaczej Szober) urodził się 30 sierpnia 1846 roku w Lublinie. Był najstarszym synem kupca Jerzego Schobera (urodzony w 1817) i Zofii z Kselowskich (urodzona w 1827)5. Ojciec Feliksa wywodził się z miasta Gottschee (dziś Kočevje na południu Słowenii), wówczas leżącego w granicach Cesarstwa Austriackiego. Przybył do Lublina wraz z młodszym bratem Piotrem (ur. 1819) w połowie 1844 roku i tutaj 27 listopada 1845 roku wziął ślub z Zofią, córką Onufrego i Emilii z Czempińskich ${ }^{6}$. W Lublinie

1 D. Bartol, Bronisław Wieczorkiewicz (27 III 1904-5 IX 1974), „Biuletyn Polonistyczny” 1975, 18/1 (55), s. 88-91.

2 Bibliografię dorobku literackiego Feliksa Schobera można znaleźć w: Szober Feliks, [w:] Literatura pozytywizmu i Młodej Polski. Hasła osobowe M-Ś, oprac. zespół pod kier. Z. Szweykowskiego i J. Maciejewskiego, Warszawa 1977, s. 643-645.

3 Warto wspomnieć, że jeden z rękopisów sztuk Schobera - komedia w dwóch aktach Naprzeciwko - została wymieniona w źródłach do słownika gwary warszawskiej autorstwa Wieczorkiewicza - zob. B. Wieczorkiewicz, Stownik gwary warszawskiej XIX wieku, Warszawa 1966, s. 83.

4 Biografia Feliksa Schobera została opracowana głównie w oparciu o: R. Skręt, Schober (Szober) Feliks Józef, [w:] Polski Stownik Biograficzny, T. 35, z. 4, Schilling Jan-Schroeder Eliasz, red. H. Markiewicz, Warszawa 1994, s. 583-584.

5 Archiwum Państwowe w Lublinie (dalej: APL), Akta stanu cywilnego Parafii Rzymskokatolickiej Katedralnej św. Jana w Lublinie, seria: 2.4 - Księgi wtóropisowe urodzeń, małżeństw i zgonów (duplikaty), sygn. 28, nr 264 (chrzty).

6 Tamże, sygn. 26, nr 86 (śluby). 
ustatkował się także Piotr, który 21 maja 1846 roku wstąpił w związek małżeński z Marianą Beer?

W Lublinie, oprócz Feliksa, małżonkowie Jerzy i Zofia Schoberowie doczekali się jeszcze dwóch synów: Antoniego Paulina (30 maja 1848 roku) oraz Aleksandra Stanisława (14 listopada 1850 roku) ${ }^{8}$. W listopadzie 1851 roku rodzina wciąż mieszkała w Lublinie ${ }^{9}$. Z czasem przeniosła się do Warszawy, co musiało nastąpić po 1854 roku, gdyż nie odnotowuje jej członków spis mieszkańców Warszawy z tego roku ${ }^{10}$, ale przed 16 czerwca 1858 roku Tego dnia bowiem w mieszkaniu przy ul. Freta nr 262 Jerzemu i Zofii urodził się czwarty syn, któremu na chrzcie świętym nadano imiona Józef Wawrzyniec (Laurenti) ${ }^{11}$. Tak więc do stolicy Królestwa Polskiego Feliks przeprowadził się w wieku około 12 lat.

Nie mając jeszcze 18 lat, przyszły literat zadebiutował 19 lutego 1864 roku jako aktor na scenie Warszawskich Teatrów Rządowych w niewielkiej roli Żyda w sztuce Dożywocie Aleksandra Fredry. Na tym jednym epizodzie się nie skończyło, gdyż od 1 stycznia następnego roku otrzymał angaż w chórze wspomnianej instytucji. Równolegle - w latach 1865-1866 - doskonalił swój warsztat aktorski w Szkole Dramatycznej i Szkole Śpiewu przy Teatrach Warszawskich ${ }^{12}$, co być może przyczyniło się do faktu, że w 1868 roku zaczął pracować w Warszawskich Teatrach Rządowych już jako aktor. Ze względu jednak na nieodpowiednie warunki fizyczne oraz ogromną nieśmiałość otrzymywał wyłącznie pomniejsze role (takie jak Gracjano w Otellu Williama Szekspira czy Organista w Okrężnem Józefa Korzeniowskiego), w tym również w operach i wodewilach, gdzie wykorzystywano jego przyjemną barwę głosu. Od 1870 roku zaczął pełnić dodatkowo funkcję pomocnika reżysera, tak zwanego ,informatora komedii”, a od czasu do czasu wykonywał także obowiązki

7 Tamże, sygn. 28, nr 25 (śluby).

8 Tamże, sygn. 31, nr 158 (chrzty); tamże, sygn. 34, nr 364 (chrzty).

9 Chrzest Aleksandra Stanisława odbył się rok po jego urodzeniu, 13 listopada $1851 \mathrm{r}$. w parafii katedralnej św. Jana w Lublinie: tamże, sygn. 34, nr 364 (chrzty).

10 Skorowidz mieszkańców miasta Warszawy z przedmieściami na rok 1854, Warszawa 1854, s. 290 .

11 Archiwum Państwowe w Warszawie (dalej: APW), Akta stanu cywilnego parafii rzymskokatolickiej Nawiedzenia NMP w Warszawie, sygn. 29, s. 232, nr 464.

12 Z. Wilski, Polskie szkolnictwo teatralne 1811-1944, Wrocław 1978, s. 211. 
inspicjenta ${ }^{13}$. Przydawała mu się do tego bardzo dobra znajomość mechaniki sceny, toteż często chwalono go za sprawną pracę ${ }^{14}$. Przewodnik warszawski informacyjno-adressowy na rok 1870 odnotowuje, że Feliks jako „,artysta Teatrów Warszawskich" mieszkał wtedy wraz z matką Zofią przy ul. Nowomiejskiej 16-18. Jego brat Aleksander był w tym czasie subiektem handlowym przy ul. Miodowej 4, zaś ojciec rezydował przy ul. Dunaj Szeroki $9^{15}$.

Równolegle z pracą w teatrze Feliks Szober zajmował się działalnością literacką. W 1864 roku opublikował w 46 numerze warszawskiego „Tygodnika Mód" liryk Nieskończoność, co uważane jest za jego debiut literacki. Pisał także sztuki: już w 1868 roku warszawski Teatr Rozmaitości wystawił jego dwie jednoaktówki - Stara pannę oraz Lekcję śpiewu (wkrótce ogłoszone drukiem). Obydwa utwory - choć dobrze przyjęte przez publiczność - nie otrzymały zbyt pochlebnych recenzji (sztukom zarzucano między innymi wtórność oraz brak realizmu w konstrukcji postaci). Mimo to krytycy doceniali u autora lekkość stylu, zręczność w prowadzeniu intrygi oraz dowcip, a nawet dostrzegali przebłyski prawdziwego talentu, w którego rozwinięciu pomogłaby dalsza praca oraz studiowanie arcydzieł światowego i polskiego dramatu ${ }^{16}$.

W 1871 roku teatrzyk Eldorado wystawił kolejną jednoaktówkę Schobera, Przyjemności wiejskie, natomiast Teatr Rozmaitości - trzyaktową wierszowaną komedię Znakomici, mającą stanowić satyrę na grafomanów, którą autor

13 Inspicjent to pracownik teatru prowadzący przedstawienie i odpowiedzialny za jego planowy przebieg. Do jego obowiązków należy m.in. nadzorowanie punktualnych wejść aktorów na scenę, decyzje o podnoszeniu i opuszczaniu kurtyny czy dopilnowanie przestrzegania ciszy za kulisami. W polskich teatrach inspicjenci pojawili się w 2 poł. XVIII w. (D. Pioskuta-Włodek, Inspicjent [online], http://www.encyklopediateatru.pl/hasla/90/inspicjent [dostęp: 02.01 .2020 r.]).

14 E. Partyga, „Podróż po Warszawie”, czyli widz-konsument, [w:] tejże, Wiek XIX. Przedstawienia, Warszawa 2016, s. 290.

15 Przewodnik warszawski informacyjno-adressowy na rok 1870, Warszawa 1870, s. 329. Co ciekawe, przy ul. Dunaj 11 mieszkał Juliusz Schober, „artysta Teatrów Warszawskich”, którego pokrewieństwo z rodziną Feliksa Schobera nie powinno ulegać wątpliwości. Możliwe, że był to brat Jerzego i Piotra Schoberów, który w przeciwieństwie do nich od razu przybył do Warszawy i tu rozpoczął karierę teatralną. Możliwe więc, że jako stryj Feliksa miał wpływ na jego zainteresowanie sztuką i umożliwił mu debiut sceniczny w $1864 \mathrm{r}$. Fakt ten wymaga jeszcze dalszych badań.

16 Zob. [J. Kotarbiński], Kronika teatralna, „Przegląd Tygodniowy” 1868, R. 3, nr 13, s. 121-122; Al., Teatra Warszawskie: dnia 15 (27) marca, „Dziennik Warszawski” 1868, R. 5, nr 61, s. 583-586; W. Szymanowski, Przeglad teatralny, „Tygodnik Illustrowany” 1868, t. 1, s. 157; Tegpż, Przegląd teatralny, „Tygodnik Illustrowany” 1868, t. 2, s. 111; E. Lubowski, Przegląd teatralny, „Bluszcz” 1868, R. 3, nr 39, s. 248. 
napisał trzy lata wcześniej. W 1876 roku z inspiracji Karola Doroszyńskiego, dyrektora objazdowej grupy aktorskiej z Poznania występującej w warszawskich teatrach ogródkowych ${ }^{17}$, powstała najbardziej znana sztuka Schobera, wodewil Podróż po Warszawie. Operetka komiczna w 7 obrazach, do którego muzykę napisał Adolf Sonnenfeld. Jej prapremiera miała miejsce 16 września 1876 roku w warszawskim teatrzyku ogródkowym „Tivoli” i - jak zauważa Witold Filler - stanowiła jeden z punktów zwrotnych w historii tego rodzaju teatrów, mających duży wpływ na ich repertuar czy nawet na repertuar całego teatru polskiego ${ }^{18}$. Ten oryginalny na tle ówczesnego polskiego dramatu utwór, zakładający pozbawioną dydaktyzmu rozrywkę, przedstawia wizytę w Warszawie prowincjonalnego szlachcica Barnaby Fafuły wraz z rodziną, w trakcie której odwiedzają oni popularne w owym czasie wśród warszawian miejsca spotkań i zabaw. Zaletą wodewilu jest nasycenie realiami dnia codziennego, przedstawiona $\mathrm{w}$ nim galeria warszawskich typów wraz z charakterystycznymi zachowaniami oraz językiem, a także uchwycona odrębność obyczajowa przedstawianego środowiska ${ }^{19}$. Jak dowodzi Ewa Partyga, sztuka ta odegrała ważną rolę w procesie narodzin ludycznej nowoczesności²0:

Teatrzyki ogródkowe, dla których pisał Szober, były jednym z przejawów kultury atrakcji charakterystycznej dla dziewiętnastowiecznego miasta. A sam wo-

17 Teatry ogródkowe to funkcjonujący w sezonie letnim rodzaj teatrów na świeżym powietrzu, organizowanych przy warszawskich restauracjach i skierowanych do szerokiej publiczności. Za oficjalną datę ich powstania uważa się rok 1868, a działały aż do 1907 roku (jednakże okres ich największej popularności trwał do około 1882 r.; w tym czasie przyciągały często większą widownię niż repertuar Warszawskich Teatrów Rządowych). Do najważniejszych należały między innymi: Alhambra, Alkazar, Belle-Vue, Eldorado i Tivoli. Podstawę repertuaru teatrzyków ogródkowych stanowiły rodzime komedie, często tworzone na zamówienie dyrektorów występujących w nich trup teatralnych, aczkolwiek próbowano niekiedy śmiałych eksperymentów. Ówcześni krytycy, przynajmniej początkowo, uważali sceny ogródkowe za sztukę mało ambitną, której zasadniczym celem miało być edukowanie widzów. (K. Kurek, Teatry ogródkowe [online], http://www. encyklopediateatru.pl/hasla/271/teatry-ogrodkowe [dostęp: 03.01 .2020 r.]). Utorowały one drogę późniejszym teatrom prywatnym (E. Szwankowski, Teatry Warszawy w latach 1765-1918, Warszawa 1979, s. 145). Więcej informacji na temat teatrów ogródkowych można znaleźć w monografii Witolda Fillera Melpomena i piwo (Warszawa 1960).

18 Tamże, s. 119.

19 J. Michalik, Schober, Szober, Feliks, [w:] Literatura Polska. Przewodnik encyklopedyczny, t. 2., $N$-Ż, red. Cz. Hernas, A. Hutnikiewicz, J. Krzyżanowski i in., Warszawa 1985, s. 344-345.

20 E. Partyga, dz. cyt., s. 265-328. 
dewil został skonstruowany tak, by ukazać całe spektrum rozrywek i uciech, które te kulturę współtworzyły. W tekście nie brakowało odwołań do konkretnych miejskich doświadczeń, z którymi przychodzili do teatru widzowie. [...] Na scenie i na widowni Eldorado, Alhambry czy Tivoli znajdowała wyraz wieloetniczność i wielojęzyczność kultury tamtych czasów ${ }^{21}$.

Sztuka zyskała wielkie powodzenie wśród publiczności a także spotkała się z dość pochlebnymi recenzjami, chwalącymi talent i dowcip autora ${ }^{22}$, co skutkowało wzrostem popularności Schobera oraz zapotrzebowania na jego twórczość.

Na kolejne premiery autorskich dzieł Schobera trzeba było poczekać dwa lata. W 1878 roku wystawiono operetkę w sześciu obrazach Modniarka warszawska oraz pięcioaktową Barnaba Fafuła i Jóżo Grojseszyk na wystawie paryskiej (powstałą na fali ogromnej popularności Podróży... jej swoistą kontynuację). Jak czytamy u Jana Michalika, sztuki te nie dorównywały poziomem poprzedniczce, co prawdopodobnie wynikało z ogromnego pośpiechu, w jakim były tworzone ${ }^{23}$ (Wystawa ... miała powstać w dwa dni; mimo to, jak zauważa Witold Filler, trafiają się w niej znakomite fragmenty ${ }^{24}$ ). W 1879 roku premierę miała operetka komiczno-fantastyczna w 5 aktach Piekło, w której autor starał się zgodnie z zaleceniami krytyków wprowadzić poważniejszą tematykę:

[...] próbował ukazać Szober przekrój ludzkich wad i grzechów, potraktowanych z konieczną w wodewilu naiwnością, lecz dobranych trafnie i niebanalnie. Próby Szoberowskiej satyry okrzyczano jednak jego „sceniczny humbug”, a zazdrośni „koledzy” sprawili mu iście piekielną łaźnię zjadliwymi recenzjami25.

Ze względu na problemy finansowe oraz konieczność zabezpieczenia potrzeb matki i rodzeństwa Schober nie mógł w pełni poświęcić się twórczości

21 Tamże, s. 269.

22 A. Łuksza, Feliks Schober-Podróż po Warszawie [online], http://www.encyklopediateatru.pl/przedstawienie/68247/podroz-po-warszawie [dostęp: 04.01.2020 r.].

23 J. Michalik, dz. cyt., s. 345.

24 W. Filler, dz. cyt., s. 125-127.

25 Tamże, s. 127-128. 
teatralnej, podejmował natomiast wiele prac dodatkowych (sytuację autora dobrze opisuje jego przyjaciel Wiktor Gomulicki w poświęconym mu opowiadaniu Coelio ${ }^{26}$ ). W 1868 roku zatrudnił się w „Kurierze Warszawskim” jako sprawozdawca teatralny, thumaczył także libretta operowe i operetkowe (między innymi Mignon z muzyką Ambroise'a Thomasa, Piękna perfumiarka z muzyką Jaquesa Offenbacha, Córka pani Angot z muzyką Charlesa Lecocq), pisał kuplety, za które był doceniany przez krytykęe27, czy satyry. Od czasu do czasu tworzył i publikował również utwory poetyckie, w tym liryki o tematyce miłosnej, a także przekłady oraz teksty piosenek (w tym do utworu chóralnego Flisaki Adama Müncheimera).

Feliks Schober zmarł nagle na serce o godzinie 5 rano 16 sierpnia 1879 roku w Warszawie, jedenaście dni po premierze swej sztuki Piekło. Mieszkał wówczas przy Rynku Starego Miasta nr 43. W metryce zgonu Feliksa zapisano, że był artystą dramatycznym warszawskich teatrów i literatem ${ }^{28}$. Dwa dni póź-

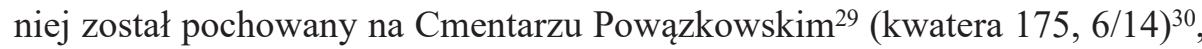
a w ostatniej drodze na cmentarz miał mu towarzyszyć kilkutysięczny tłum ${ }^{31}$. Warto odnotować, że fakt zgonu Feliksa do akt stanu cywilnego przedstawili jego bracia - Aleksander, określony jako kupiec, oraz Antoni, cukiernik.

Aleksander, żonaty z Pauliną Nowakowską, zmarł w 1889 roku $^{32}$. Ojciec Feliksa przeżył syna o 12 lat, zmarł 10 lipca 1891 roku w wieku 75 lat w swoim mieszkaniu przy ul. Miodowej nr 495, a zgon do urzędu stanu cywilnego zgłosił najmłodszy syn Józef, określony jako „artysta Warszawskich

26 W. Gomulicki, Coelio. O Feliksie Schoberze, [w:] tegoż, Warszawa wczorajsza, oprac. J. W. Gomulicki, Warszawa 1961, s. 361-377. Juliusz W. Gomulicki określił je jako najlepszą biografię ,psychologiczną" pisarza. Zob. tamże, s. 497.

27 M. G[awalewicz], Feliks Szober, „Kłosy” 1879, T. XXIX, nr 745, s. 234.

28 APW, Akta stanu cywilnego parafii rzymskokatolickiej św. Jana Chrzciciela w Warszawie, sygn. 95, nr 338 (zgony).

29 Odnotowuje go S. Szenic w tomie Cmentarz Powązowski 1851-1890. Zmarli i ich rodziny, Warszawa 1982, s. 291.

30 Fotografia nagrobka rodziny Schoberów (zapisanych pod nazwiskiem Szober) znajduje się na blogu Moje cmentarze, dostępnym pod adresem https://mojecmentarze.blogspot.com/2015/05/ feliks-szober.html [dostęp: 04.01.2020 r.]).

31 Wiadomości miejscowe, „Kurier Warszawski” 1879, nr 184, s. 3.

32 APW, Akta stanu cywilnego parafii Przemienienia Pańskiego w Warszawie, sygn. 22, nr 125 (zgony). 
Teatrów"33. Z czterech braci Schoberów dzieci doczekał się tylko Aleksander, którego potomkowie żyli w Warszawie jeszcze przed 1939 roku $^{34}$.

O wartości twórczości Schobera może świadczyć fakt, że jego utwory grano jeszcze długo po jego śmierci, a przedstawienia spotykały się nie tylko z powodzeniem u publiczności, ale i zyskiwały wreszcie pozytywne recenzje, w których chwalono talent autora ${ }^{35}$. Wracano do nich także w okresie powojennym, przede wszystkim do Podróży po Warszawie, co odnotowuje między innymi serwis e-teatr ${ }^{36}$. Przykładowo w latach 60. XX wieku Teatr Polskiego Radia zrealizował Modniarkę warszawska oraz wspomnianą Podróż a pod koniec lat 80 . XX wieku ten drugi tytuł miał swoją premierę również w Teatrze im. Stefana Żeromskiego w Kielcach. Barnaba Fafuła i Jóżo Grojseszyk na wystawie paryskiej doczekał się w 1973 roku przeróbki w wykonaniu Teatru Telewizji, a w 2013 roku wodewil na motywach Podróży po Warszawie wystawił warszawski teatr niezależny Pijana Sypialnia ${ }^{37}$.

Niemniej Feliks Schober podzielił los innych dramatopisarzy z okresu pozytywizmu ${ }^{38}$ i jest obecnie twórcą raczej nieznanym, a jego twórczość nie doczekała się wznowień. Autor sporo utworów pozostawił w rękopisach, z których część przechowuje w swoich zbiorach Biblioteka Narodowa.

\section{Nieznane rękopisy}

Jak zaznaczono we wstępie, od lat 80. rękopisy Schobera znajdują się także w kolekcji Biblioteki Uniwersyteckiej im. Jerzego Giedroycia. W 2018 roku zostały wpisane do jej katalogu komputerowego pod sygnaturami Rps - 2, Rps - 3 i Rps - 4. Poniżej znajdują się szczegółowe informacje na temat stanu

33 Tamże, sygn. 24, nr 82 (zgony).

34 Aleksander Schober doczekał się dzieci: Marii Anieli, Aleksandry, Mieczysława Jana Kantego, Janiny Wacławy i Wacława Jerzego. W 1908 r. Mieczysław Jan Kanty wstąpił w związek małżeński z Heleną Stanisławą Dzierżanowską.

35 Zob. M. G[awalewicz], Kronika tygodniowa, „Tygodnik Ilustrowany” 1890, T. II, s. 26.

36 Feliks Schober - wszystkie utwory [online], http://www.e-teatr.pl/pl/realizacje/1676,autor. html [dostęp: 02.01.2020 r.].

37 TEATR PIJANA SYPIALNIA - Wodewil warszawski [online], https://www.often.com.pl/ teatr-pijana-sypialnia-wodewil-warszawski/ [dostęp: 02.01.2020 r.].

38 Zob. Z. Poznański, Stan badań nad dramatem polskim okresu pozytywizmu, [w:] Dramat i teatr pozytywistyczny. 1, red. nauk. D. Ratajczak, Wrocław 1992, s. 9-22. 
i zawartości każdego z nich. Omawiając rękopisy, intencjonalnie pomijamy opis treści trzech sztuk Feliksa Schobera, pozostawiając ich analizę oraz porównanie z późniejszą twórczością tego autora badaczom pozytywistycznego dramatu.

Prezentowane poniżej trzy rękopisy to czystopisowe bruliony, które Feliks Schober przeznaczył na wpisanie do nich treści sztuk: Koleta czyli Chrześcijanie za Nerona. Opera $w 4^{\text {ch }}$ aktach (datowana na 3 kwietnia 1863 roku), pozbawionej początkowych kart o nieznanym tytule (datowana na 8 czerwca 1863 roku), oraz Naprzeciwko. Komedya $w 2^{\text {ch }}$ aktach oryginalnie wierszem napisana przez Feliksa Schober (datowana na 16 marca 1864 roku). W późniejszym okresie puste strony rękopisów były przez autora wykorzystywane na potrzeby spisywania $\mathrm{w}$ formie brudnopisu innych, mniejszych wierszowanych utworów poetyckich lub luźnych zapisków (tylko część z nich została datowana na wrzesień 1866 roku). Wynika z tego, że rękopisy te powstały w krótkim okresie między kwietniem 1863 roku a marcem 1864 roku, a więc mniej więcej w czasie oficjalnego debiutu scenicznego Schobera. Autor miał więc wówczas zaledwie 17/18 lat. Z pewnością liczył na to, że dzieła te otworzą mu drogę do kariery jako autora sztuk scenicznych oraz aktora miejscowych teatrów. Pozostały one jednak w formie rękopisów i zapewne nigdy nie zostały wystawione na scenie, mogły jednak stanowić istotny punkt wyjścia do późniejszych sztuk Feliksa Schobera.

\section{Sygn. Rps - 2}

Rękopis w postaci brulionu szerokości $16,5 \mathrm{~cm}$ i wysokości $20 \mathrm{~cm}$, pierwotnie szytego, aktualnie rozerwanego (nici zachowane szczątkowo), w okładce kartonowej, oklejonej czarnym papierem marmurkowym, z której zachowało się tylko skrzydło przednie. Grzbiet zachowany tylko częściowo. Aktualnie brulion liczy 33 karty z papieru maszynowego, składa się z dwóch składek, z których pierwsza liczy 10 kart (wyrwane karty), druga 13, przy czym w tej wycięto drugą połowę składki. Ogólny stan rękopisu należy uznać za dobry.

Cały zachowany brulion zawiera rękopis utworu pod tytułem Koleta czyli Chrześcijanie za Nerona. Opera $w 4^{\text {ch }}$ aktach. Rękopis spisany atramentem jako czystopis z pewną liczbą późniejszych poprawek i uzupełnień czynionych przez autora ołówkiem i atramentem. Utwór złożony z czterech aktów podzielonych na sceny: od 1 do $4 \mathrm{w}$ pierwszym akcie, od 5 do $11 \mathrm{w}$ drugim 
akcie, od 12 do $19 \mathrm{w}$ trzecim, a scena $20 \mathrm{w}$ akcie czwartym. Osoby występujące w utworze: Neron cesarz rzymski, Tyreniusz jego ulubieniec, Koleta córka Tyreniusza, biskup Urban, Awersus, Walerjan jego brat, Helja (ci czterej spięci klamrą i opisani jako Chrześcijanie), Agre niewolnica Kolety, jeden z senatorów, jeden z rycerzy, niewolnice, niewolnicy, dworzanie Nerona, senatorowie, rycerze, żotnierze, Chrześcijanie, dyakoni, naród i Chór Aniołów. Na końcu sceny 8 oraz aktu trzeciego wpisane w otoku inicjały F. S., natomiast przy początku sceny 19 (karta 27v) i na końcu aktu czwartego - inicjały J. M. Na końcu utworu data 3 kwietnia 1863 oraz podpisy Feliks Schober Józef Mozes.

Na k. 1-1v poniżej tytułu sztuki Koleta [...] niedatowany utwór poetycki w formie brudnopisu, z licznymi poprawkami i zmianami, zaczynający się od słów Szczerych uczuć stówek parę. W dalszej części tekstu znajduje się ustęp: koleżeństwo niechaj stare | udowodnia i uświęca $\mid \dot{z} e$ Cię kocham - daję parot na to parol $\mid$ daje ci Mroziński Karol. Karol Mroziński (1819-1883) był również warszawskim aktorem, znanym głównie z pomniejszych ról. W latach 1839-1870 pracował jako chórzysta, zaś w latach $1870-1881$ był zatrudniony w dyrekcji Warszawskich Teatrów Rządowych ${ }^{39}$.

\section{Sygn. Rps - 3}

Rękopis w postaci brulionu szerokości $16 \mathrm{~cm}$ i wysokości $19,5 \mathrm{~cm}$, szytego, w kartonowej oprawie oklejonej grubszym papierem imitującym skórę. Zachowało się tylko tylne skrzydło oprawy oraz niewielki fragment grzbietu. Aktualnie brulion liczy 36 kart z papieru maszynowego i jest wykonany z dwóch składek liczących po 12 kart (24 strony), natomiast pierwsza składka - z powodu rozerwania nici oprawy - oderwała się od bloku brulionu i zaginęła (zachowały się tylko dwie ostatnie karty). Druga połowa ostatniej składki została obcięta tuż przy grzbiecie. Mimo braku początku brulionu i przedniego skrzydła okładki ogólny stan rękopisu dobry.

Cały zachowany brulion zawiera rękopis utworu o nieznanym tytule podzielonego na cztery obrazy. Rękopis rozpoczyna się w połowie obrazu II (początek utworu, treść obrazu I oraz część obrazu II znajdowały się na brakującej pierwszej składce brulionu), obraz III zapisano na kartach 11-21, zaś obraz

39 Karol Mroziński [online], http://www.e-teatr.pl/pl/osoby/79136.html [dostęp: 04.01.2020 r.]. 
IV na kartach 22-36v. Każdy obraz podzielony został na sceny: obrazy I i II zawierały sceny od 1 do 13 (zachowany koniec sceny 10 oraz całe sceny 11 i 12), obraz III zawiera sceny od 13 do 15 , zaś obraz IV od sceny 16 do 23 . Występują postacie: Czarkiewicz, Katarzyna, Basia, Czesław, Jan, Ogryzek, Pucalski, Kaźmierz, Lisiewicz, Rembalski, Kiwryło, Agata, Barttomiej. Tekst zaopatrzony w didaskalia. Brakuje ogólnej informacji na temat miejsca akcji. W przypadku obrazu III autor zapisał: przedstawia oberżę Ogryzka w majątku Czesława - on i Agata zajęci obstugiwaniem gości, z których kilku (wieśniaków) siedzi w głębi, Barttomiej między niemi - z lewej strony sceny na przodzie siedza Kiwryto i Rembalski. Natomiast obraz IV: przedstawia komnate na zamku Czesława - po obu stronach drzwi - kilka dużych obrazów wisi na ścianach - Basia klęczy i modli się. Tekst w postaci czystopisu, z nielicznymi poprawkami i uzupełnieniami ołówkiem lub atramentem. Na ostatniej karcie 36v data $d: 8$ czerwca 1863 oraz podpis autora Feliks Schober.

\section{Sygn. Rps - 4}

Rękopis w postaci brulionu szerokości $17 \mathrm{~cm}$ i wysokości $20 \mathrm{~cm}$, szytego, oprawionego w twardą tekturową okładkę oklejoną papierem marmurkowym. Grzbiet płócienny. Brulion złożony z 6 składek liczących po 14 kart każda (28 stron). Z początkowej składki wyrwano cztery karty, dlatego cały brulion liczy 84 karty. Ogólny stan zachowania rękopisu dobry, k. 66, 67 i 78 wydarte (zachowane tylko częściowo przy grzbiecie), płótno grzbietowe rozdarte, krawędzie okładki starte i uszkodzone. Na drugiej stronie okładki pieczątka: Dr Bronisław Wieczorkiewicz | Profesor Uniwersytetu Warszawskiego.

Na k. 1-1v krótki utwór poetycki zaczynający się od słów Ja toba tylko $\dot{z} y j e, \mathrm{w}$ formie brudnopisu, $\mathrm{z}$ licznymi wykreśleniami i poprawkami oraz dopisanymi wersami. Na k. 1v dopisek innym atramentem (późniejszy?): Kiedy róża zwiędnie trocha $\mid$ Straci blask $i$ woń - $\mid$ Nikt jej wtedy już niekocha $\mid$ Każdy depcze poń. Pełny utwór Ja toba tylko żyję w wersji po poprawkach odnotowanych na k. 1-1v przepisany został ołówkiem na k. 64-65. W tej wersji także kilka poprawek i skreśleń. Wiersz bez daty, ewidentnie późniejszy niż główny utwór, którego czystopis autor wpisał na k. 2-60 w 1864 r.

Na k. 2-60 utwór pod tytułem Naprzeciwko. Komedya w $2^{\text {ch }}$ aktach oryginalnie wierszem napisana przez Feliksa Schober. Rękopis spisany atramentem jako czystopis, ale z drobnymi wykreśleniami, poprawkami i dopełnieniami 
nanoszonymi na tekst zarówno przy użyciu atramentu, jak i ołówka. W kilku miejscach ślady zeskrobywania liter i słów. Utwór złożony z dwóch aktów, z których pierwszy został podzielony na osiem scen, a drugi na siedemnaście. Tekst zaopatrzony w didaskalia. Po karcie tytułowej osoby występujące: Major, Ździsław jego synowiec, Henryk szkolny kolega Ździsława, Sędzina Starusznicka, Agnieszka jej córka (stara panna), Florentyna siostrzenica Agnieszki, Walenty ex-żolnierz, Kasia stużaca. Poniżej zapis: Rzecz dzieje się $w$ Warszawie. Na karcie 60, kończącej tekst komedii, data i podpis: Dnia 16 marca 1864. F. Schober. Na k. 32v - słabo czytelna prostokątna pieczątka ze ściętymi narożnikami, wewnątrz której u góry napis Teatr Poznański, u dołu napis nieczytelny (prawdopodobnie: Karol Doroszyński), pośrodku napis nieczytelny (prawdopodobnie data).

Na k. 69-71v utwór poetycki zaczynający się od słów O! Brońciu moja! Spiesz w imię Boże | Kędy głos serca Cię woła. Spisany atramentem w formie czystopisu, chociaż z kilkoma późniejszymi poprawkami i wykreśleniami. Utwór na końcu datowany 10/9.66 (10 września 1866 r.) i podpisany Felix.

Na k. 73-74 utwór poetycki zaczynający się od słów Ukochane dziewczę moje (inne warianty pierwszego wiersza przekreślone). Tekst w formie brudnopisu, z licznymi wykreśleniami i innymi wariantami zapisu tych samych fragmentów, $\mathrm{w}$ tym $\mathrm{w}$ formie ostatecznej na zewnętrznym i wewnętrznym marginesie w poprzek karty. Utwór na końcu datowany 12/9 66 (12 września 1866 r.).

Na k. $75-77$ v utwór poetycki zaczynający się od słów Dla czego to o bracia moi $\mid$ Uczucie w seret piersiach drży (inny wariant pierwszego wiersza, przekreślony: Łza tęsknoty życie ptynie). Tekst $\mathrm{w}$ formie brudnopisu, z licznymi wykreśleniami i innymi wariantami zapisu tych samych fragmentów. Utwór niedatowany.

Na k. $79 \mathrm{v}-80 \mathrm{v}$ niedatowany utwór poetycki zaczynający się od słów I ta tadna, i ta ładna. Tekst $\mathrm{w}$ formie brudnopisu, z licznymi wykreśleniami i innymi wariantami zapisu tych samych fragmentów, w tym częściowo w formie ostatecznej na zewnętrznym marginesie k. 80v.

Na k. 68 niedatowane zapiski dotyczące wydatków (długów?) Schobera, w których wymienia: Pawlewskiemu, Dobroczynność, Gutowskiej, w cukierni, Szymanowskiemu, Krosińskiej, Loberyja.

K. 72 i 79 puste. 
Ewa Witkowska, Wiesław Wróbel, Nieznane rękopisy Feliksa Schobera...

\section{Zakończenie}

Niniejszy artykuł nie wyczerpuje tematu, jakim jest życie i twórczość Feliksa Schobera, ale nie taki też był zamiar jego autorów. Mamy nadzieję, że zainspiruje on badaczy dziewiętnastowiecznego dramatu czy teatru warszawskiego do przypomnienia postaci tego niedocenianego za życia, a obecnie raczej zapomnianego komediopisarza, który odegrał jednak dość istotną rolę w historii polskiego teatru. Przechowywane w zbiorach Biblioteki Uniwersyteckiej im. Jerzego Giedroycia rękopisy z pewnością dostarczą nowych informacji na jego temat.

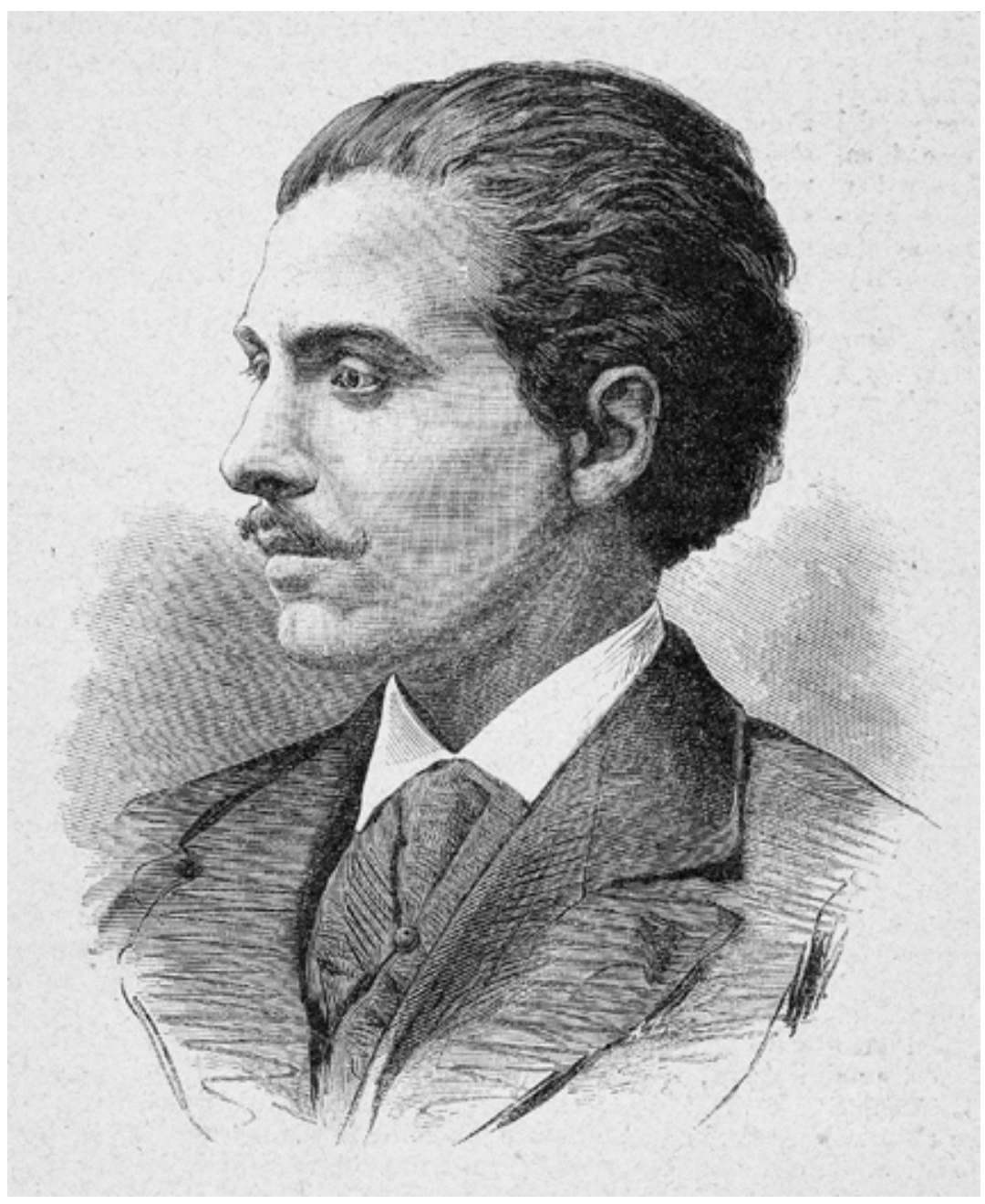

Feliks Schober 


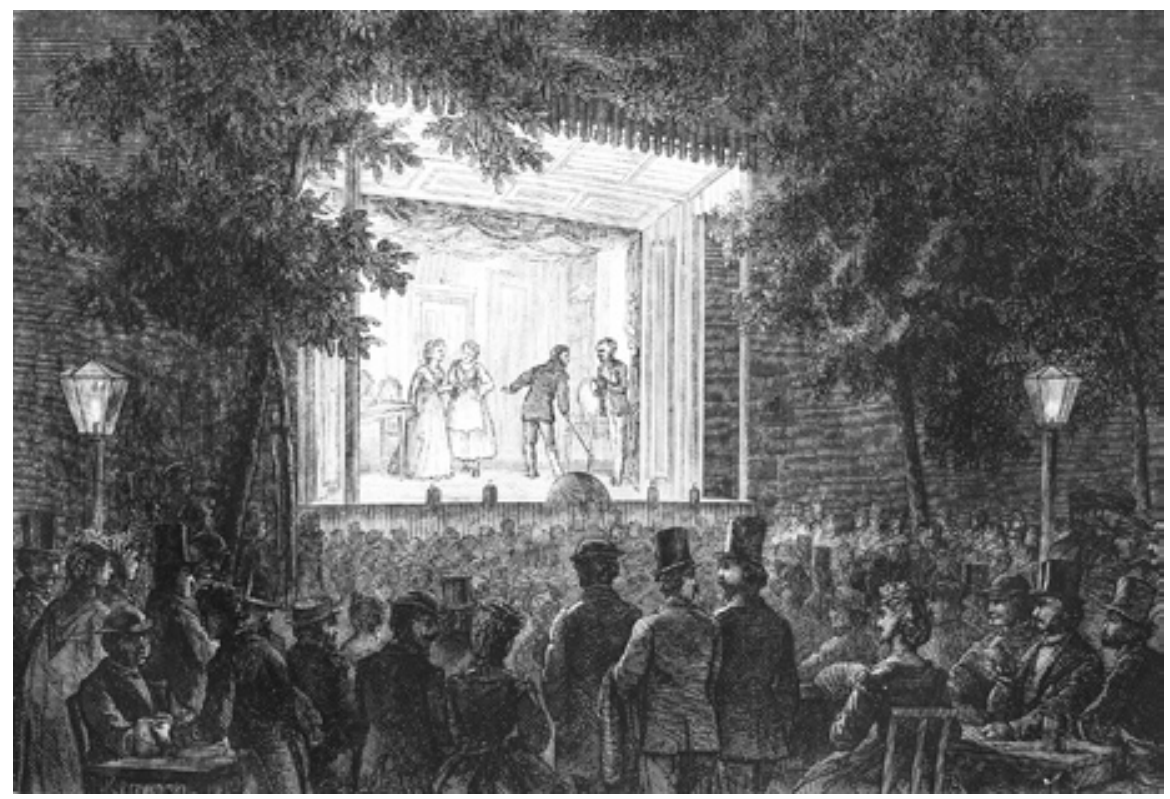

Letni Teatr Alhambra w Warszawie

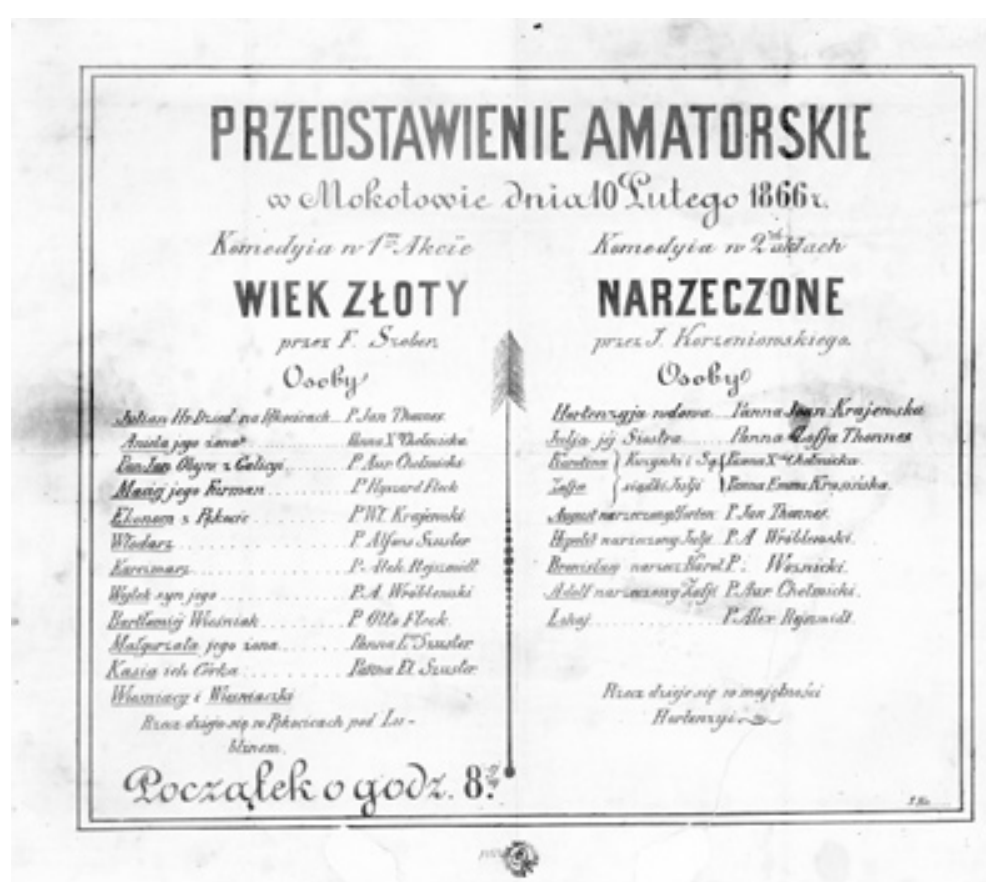

Afisz teatralny 
Ewa Witkowska, Wiesław Wróbel, Nieznane rękopisy Feliksa Schobera...

\section{Bibliografia}

\section{Źródła archiwalne}

Akta stanu cywilnego parafii Przemienienia Pańskiego w Warszawie, sygn. 22, 24.

Akta stanu cywilnego Parafii Rzymskokatolickiej Katedralnej św. Jana w Lublinie, seria: 2.4 - Księgi wtóropisowe urodzeń, małżeństw i zgonów (duplikaty), sygn. $26,28,31,34$.

Akta stanu cywilnego parafii rzymskokatolickiej Nawiedzenia NMP w Warszawie, sygn. 29.

Akta stanu cywilnego parafii rzymskokatolickiej św. Jana Chrzciciela w Warszawie, sygn. 95.

Archiwum Państwowe w Lublinie.

Archiwum Państwowe w Warszawie.

\section{Opracowania}

Al., Teatra Warszawskie: dnia 15 (27) marca, „Dziennik Warszawski” 1868, R. 5, nr 61, s. 583-586.

Bartol D., Bronisław Wieczorkiewicz (27 III 1904-5 IX 1974), „Biuletyn Polonistyczny" $1975,18 / 1$ (55), s. 88-91.

Feliks Schober - wszystkie utwory [online], http://www.e-teatr.pl/pl/realizacje /1676, autor.html [dostęp: 02.01.2020 r.].

Filler W., Melpomena i piwo, Warszawa 1960.

G[awalewicz] M., Feliks Szober, „Kłosy” 1879, T. XXIX, nr 745, s. 234.

G[awalewicz] M., Kronika tygodniowa, „Tygodnik Ilustrowany” 1890, T. II, s. 26.

Gomulicki W., Coelio. O Feliksie Schoberze, [w:] tegoż, Warszawa wczorajsza, oprac. J. W. Gomulicki, Warszawa 1961, s. 361-377.

Karol Mroziński [online], http://www.e-teatr.pl/pl/osoby/79136.html [dostęp: 04.01.2020 r.].

[Kotarbiński J.], Kronika teatralna, „Przegląd Tygodniowy” 1868, R. 3, nr 13, s. $121-122$.

Kurek K., Teatry ogródkowe [online], http://www.encyklopediateatru.pl/hasla/271/ teatry-ogrodkowe [dostęp: 03.01.2020 r.].

Lubowski E., Przegląd teatralny, „Bluszcz” 1868, R. 3, nr 39, s. 248.

Łuksza A., Feliks Schober - Podróż po Warszawie [online], http://www.encyklopediateatru.pl/przedstawienie/68247/podroz-po-warszawie [dostęp: 04.01.2020 r.]. 
Michalik J., Schober, Szober, Feliks, [w:] Literatura Polska. Przewodnik encyklopedyczny, t. 2. N-Ż, red. Hernas, A. Hutnikiewicz, J. Krzyżanowski i in., Warszawa 1985 , s. 344-345.

Partyga E., „Podróż po Warszawie”, czyli widz-konsument, [w:] tejże, Wiek XIX. Przedstawienia, Warszawa 2016, s. 265-328.

Pioskuta-Włodek D., Inspicjent [online], http://www.encyklopediateatru.pl/hasla/90/ inspicjent [dostęp: 02.01.2020].

Poznański Z., Stan badań nad dramatem polskim okresu pozytywizmu, [w:] Dramat i teatr pozytywistyczny. 1, red. nauk. D. Ratajczak, Wrocław 1992, s. 9-22.

Skorowidz mieszkańców miasta Warszawy z przedmieściami na rok 1854, Warszawa 1854.

Skręt R., Schober (Szober) Feliks Józef, [w:] Polski Słownik Biograficzny, T. 35, z. 4, Schilling Jan - Schroeder Eliasz, red. H. Markiewicz, Warszawa 1994, s. 583-584.

Szenic S., Cmentarz Powązkowski 1851-1890. Zmarli i ich rodziny, Warszawa 1982.

Szober Feliks, [w:] Literatura pozytywizmu i Młodej Polski. Hasła osobowe M-Ś, oprac. zespół pod kier. Z. Szweykowskiego i J. Maciejewskiego, Warszawa 1977, s. $643-645$.

Szwankowski E., Teatry Warszawy w latach 1765-1918, Warszawa 1979.

Szymanowski W., Przegląd teatralny, „Tygodnik Illustrowany" 1868, t. 1, s. 157.

Szymanowski W., Przegląd teatralny, „Tygodnik Illustrowany” 1868, t. 2, s. 111.

TEATR PIJANA SYPIALNIA - Wodewil warszawski [online], https://www.often.com.pl/ teatr-pijana-sypialnia-wodewil-warszawski/ [dostęp: 02.01.2020 r.].

Wiadomości miejscowe, „Kurier Warszawski” 1879, nr 184, s. 3.

Wieczorkiewicz B., Słownik gwary warszawskiej XIX wieku, Warszawa 1966.

Wilski Z., Polskie szkolnictwo teatralne 1811-1944, Wrocław 1978. 